Athens Journal of History - Volume 7, Issue 3, July 2021 - Pages 217-232

\title{
Serbian Royal Right to the Throne of Hungary at the Basis of the Formation of Medieval Romanian Orthodox States
}

\author{
By Stefan Staretu*
}

\begin{abstract}
This paper shows that the overall situation in the Pannonian-Balkan area led to the facts in the $14^{\text {th }}-16^{\text {th }}$ centuries on the background of which the Romanian medieval states were formed and consolidated. The origins of these facts derive from the interactions between the first Hungarian tribes who came to the Pannonian area and the situation that was encountered here, which can be staged as follows: the first stage is related to the arrival of the Hungarian tribes from the northern part of Europe and the conquest of the territory between the eastern Alps and the Dniester; the second stage is the period between the Christianization of the Hungarian King Stephen and the arrival of the Angevins. The second and the third period, post-Angevin, or rather Sigismundian-Lazarević, are epochs of colonization of different populations from the Germanic, North Pontic or Balkan space that are integrated into the noble structure of the Kingdom, consolidating its authority. The expansion of Serbian civilization came after the claim to the throne of Hungary of the Serbian King Stefan Dragutin when the Árpád dynasty came to end. Thus, the medieval Romanian Orthodox states, the Romanian Country-Wallachia and Moldavia are the rest of Andrew III's, the last of Árpádian's posterity of his Serbian posterity, and catholic Hungary, the rest of his Angevin Posterity.
\end{abstract}

\section{Introduction}

The overall situation in the Pannonian-Balkan area led to the facts of the $14^{\text {th }}$ $16^{\text {th }}$ centuries on the background of which the Romanian medieval states were formed. The origins of these realities derive from the interactions between the first Hungarian tribes that came to the Pannonian area, and the situation they stumbled on there and which can be staged as follows. The first stage is related to the arrival of the Hungarian tribes from the northern part of Europe and the conquest for the territory between the eastern Alps and the Dniester, subjugating the Slavic population living in the area and achieving a strong system of domination. The second stage is the period between the Christianization of the Hungarian King Stephen and the arrival of the Angevins. It is a period when an aristocracy of Western model emerged, following the Moravian and Slavic German model they came across, but also under the influence of the Bulgarian boyar model. This was the period that anticipated the consolidated Angevin Kingdom, which imposed a western-type organization, which came through Bohemia, German countries and Poland. The second and the third period, postAngevin or better Sigismundian-Lazarević, are epochs of colonization of different

"Executive Director, Theology and History Studies Center, St. Ephrem the New Monastery, Cristian, Brasov, Romania. 
populations from the Germanic, North Pontic or Balkan space that are integrated into the noble structure of the Kingdom, consolidating its authority. The contrast between the civilizing power of the Balkan Byzantium and the military power of the Hungarian aristocracy (which didn't have an advanced level of civilization), led to conflicts that would result in the anti-Orthodox war of the Hungarian nobility, carried out under the leadership of the Angevin Kings. The result of this conflict would be the founding of the Romanian countries, Wallachia and Moldavia, and the alienation of Serbia and Bosnia, but also the advent of a tradition about the Kingdom of Hungary as an Orthodox Kingdom. This was important because it confirmed the influence of Byzantine Christianity by Byzantine and Bulgarian descent in the area before the arrival of some populations from the Western Balkans, related to the Serbian Church, leading to a symbiosis of the three major Orthodox churches in the Balkans. ${ }^{1}$ These Orthodox churches were a Byzantine one (which assimilated the Bulgarian), the Bulgarian and the Serbian, of the new nobility that would find the extra-Carpathian states, The Romanian Country and Moldavia, which would form the great aristocracy, as well as a new infusion of Orthodox population that get under the dominion of large Hungarian families through marriages whose traces got lost in time.

\section{Historical Hungary and Newcomers}

Historic Hungary has not lost touch with newcomers and their areas of origin, the German and Western-Balkan ones. Other waves of immigrants from the Western Balkans came in the $15^{\text {th }}-16^{\text {th }}$ centuries, with the decrease of Serbia's power in the process of its integration into the new Ottoman state. ${ }^{2}$ This population had a much higher social and cultural level than the old settlers' and created a new cultural stratum, which would express itself politically through the influence of Branković's relatives in the politics of Hungary and its client states The Romanian Country - Wallachia and Moldavia - in the $15^{\text {th }}$, but especially in the $16^{\text {th }}$, centuries.

Historic Hungary is thus set up in a space where orthodoxy was experienced and manifested historically at all social levels, from serfs, to enslaved workers on the estates of great feudal lords such as Wass, Telegdi or Banffy families. This also occurred at the level of a colonized nobility, like the one in Maramureş or Hațeg, with their extensions in Moldavia and Muntenia, or even at the level of the great Serbian royal families' members such as Lazarević or Branković, who took refuge and settled there. The last wave is by far the most important, because it brought

1. Boško I. Bojović, L'Ideologie Monarchique dans les Hagio-Biographies Dynastiques du Moyen Age Serbe. Orientalia Christiana Analecta 248 (Roma: Pontifcio Istituto Orientale, 1995).

2. Sima Ćirković, La Serbie au Moyen Age (Paris: Zodiaque, Paris, 1992). 
orthodoxy to eastern historical Hungary, a prestige that it no longer had, and a royal dimension it could never have had on the background set by Hungarian autonomous states as voivodeships in the contact area between the extraCarpathian Cumans and the Bulgarians by the Danube. The Bulgarians influenced the structure and the ideology of the new Orthodox extra-Carpathian states and contributed together with the Cumans to create a new aristocratic structure. This led to the formation of an autonomous nobility of unrelated families who came from Serbia through the short Transylvanian period. A similar role was played by large families from Kievan Russia who took refuge in the north of Moldavia and constituted the force of the great Moldavian nobility unrelated to the Bogdan family (Mihul de la Dorohoi, for example, or Brăescu, Boris Braevici's). The papacy's efforts to keep Hungary's space under the Latin church control, and the use of the Hungarian nomadic origin aristocracy for this purpose under the coordination of a great monarch belonging to a strong royal European family, Louis of Anjou, show us the importance of Hungary in the context of western Christianity's anti-Byzantine policy. This constituted one of the two centers of Catholic action in relation to Byzantium, along the path of the Fourth Crusade, and later the Polish-Lithuanian one. However, the Orthodox nobility of Illyrian origin in these areas had a policy of great resistance, which combined military virtues and social status, creating conditions for them to retain their position as great nobles during the Hungarian stage. They couldn't prevent the remaining descendants in Hungary from mixing with the peasantry bearing noble titles, thus taking a lower social position. This was the case in Maramureş (back to the first idea), which combined the social status with an intransigent position in the context of defending Orthodox religious independence.

\section{The Angevin Kingdom and Dušan's Serbian Empire}

When an explicit conflict broke out between the Angevin Kingdom and Dušan's Serbian Empire (1346-1355), the Transylvanian nobility assumed an offensive position against Hungarian Catholicism, a position probably achieved with financial and military support from Stefan Dušan (as evidenced by the monetary treasury of Cuhea), ${ }^{3}$ which led to the founding of new Orthodox states.

Medieval Serbia was at the crossroads of the Slavic-Bulgarian, the Byzantine and the Italic worlds. This made Western spirituality and chivalric practices coexist with Byzantine ones in Serbia. The conflict between Byzantium and the Western world caught Serbia by surprise during the bustle of its state consolidation; titanic moments that are related to a still rarely-studied

3. Denis Căprăroiu, "Opinii istoriografice despre unul dintre voievozii cu numele Bogdan din secolul al XIV-lea," Analele Universităţii din Craiova. Seria Istorie XVI, no. 1 (2011): 27-43. 
phenomenon connected to the great movements of the elites in times of states' organization.

Stefan Nemanja (1166-1196) succeeded in Raška and Diokleia to some sovereigns between East and West, from the Vojislavljevic dynasty. ${ }^{4}$ These dynasts, such as the Archon Peter (identified on a recently discovered seal), and the probable father of St. Jovan Vladimir played an important role in all the political movements in the area. Jovan Vladimir was an archetype of holiness in the Balkans as a royal martyr who could seem to foresee the future of a noble people destined, however, for an assumed sacrifice. Stefan Nemanja's departure to Raška, where he was re-baptized in the Orthodox religion (after being baptized as Latin by his parents in his childhood in Diokleia), the fight between Simeon Nemanja's successors, Stefan and Vukan, as well as Stefan Prvovencani's hesitations anticipated the close relationships between Serbia and The Holy See in Stefan Milutin's time. But Stefan Dušan (1331-1355) thoroughly changed this situation, being the first monarch to introduce autocracy in its pure meaning to the medieval Serbian society. Growing himself as emperor on the Resurrection day, he gave for the first time in the history of the Orthodox world, a monumental, combative aspect to the hostile relationship between Catholics and Orthodox. In his Zakonik, ${ }^{5}$ Dušan succeeded in turning constitutional norms into the strict canonical relationship that existed between Orthodoxy and Catholicism during the previous 200 years. The need for re-baptism for the Catholics was shocking for the diplomatic relationships with Hungary, which led to the great Angevin campaigns against Serbia. It's obvious that the elements related to the Orthodox orientation that were involved in the founding of Moldavia are related to Dušan's reaction. St. Sava was also represented in Moldavia, in Voroneț, and Bălineşti (which comes from the name Balea, as the one from leud, although the founder is the logothete Tăutu, probably also a Muşatin relative), churches built by the same Bogdan's dynasty, through Stephen the Great (1457-1504). The logothete Tăutu can be Ioan, Stephen's brother, just as Cârstea Arbure, ${ }^{6}$ Luca's father, who was said to have been claimed the throne, pretended to be Cirstea, another brother of Stephen's. So, the cult of St. Sava would have royal dynastic support.

This Legend of Roman and Vlahata is a family tradition of this family, Bogdan, considered of Serbian origin, which can be related to a Ştefan Constantin of Moldavia (homonymous with Ştefan Constantin, Milutin's brother disappeared during the advent of the first political structures in Maramureş, related to the voivode Ştefan from Maramureş, Constantin, means Costea, appointed from the

4. Zorica Zlatić Ivković, Stefanu Nemanju povodom 900 godina od rođenja (1113-2013) (Beograd: Grafoprint, Beograd, 2013).

5. Codul de Legi al lui Ștefan Dušan (Stefan Dušan's Code of Laws). Information on: http://www.Dušanov-zakonik.com/.

6. Maria Magdalena Székely, "Obârșia lui Luca Arbure. O ipotezăa," in In honorem Paul Cernovodeanu, 419-429 (Bucharest: Violeta Barbu Publisher, 1998). 
family of the Serbian Despots through the chronicler from Bistrița, wearing, in his tomb, heraldic buttons identical to Lazăr's). See in this context the existence of a Bogdan, son of Mikula, voivode of Serbia helped by the Angevin king to come to Hungary after the fall of his dominions in Herzegovina, identifiable with Bogisa, Nikola's son, from the branch of Miroslav from the Nemanids, and relative of the queen in the Kotromanic family of Hungary, that had domains near Maramureş and with Bogdan, the founder of Moldavia, although certain data about them are missing.

The symbiosis between the state's founding families and the great Bulgarian, Cuman or Russian nobles encountered in Muntenia and Moldavia can be seen in the presence of the royal councils of the new states of great feudal lords like Albul Tocsabă, Boris Braevici, together with less important boyars of Transylvanian or Maramureş origin, like Popşea, Huhulea, Albotă, Hudici, Giula, Oancea, Voico. The new great families founded by Serbian emigrants such as the Zamona family of Vlastelini in Baia de Fier, or the Balş family in Moldavia will be related to Staico's descendants; the latter being Mircea the Elder's brother. They formed the boyars' family in Bucov, including descendants of illegitimate sons of lords, forming large families such as Craiovescu, Sărățeanu, Movilă, Ganea. The social fluctuations of this great nobility would lead to important civil wars such as the one between the Dănescu and Drăculea families, followed by the one between the families of Craiovescu and Mihnea, or in Moldavia, the one between Petru Aaron's descendants and Stephan the Great's ancestors, and later between the Ganea and Arbure families (related to Aaron) and between Rareş's "clients," Movilă and Costin families. It's a space that can hardly find its identity, following noble female successions, a unique phenomenon in Europe, and assimilating the identity of ancient Serbia, as seen in the genealogical program in Argeş, in which Simeon, Sava and Lazarus of Serbia appear as the oldest, and are therefore the ancestors of the Basarab family. The role that the great Serbian nobles would play in the former eastern Hungary would lead to keeping Transylvania, Muntenia and Moldavia unconquered by the Ottomans.

\section{North Danube Orthodox Population}

There is an overlap of social categories and different stages of religious development in the history of the Orthodox population in the former eastern Hungary, up to the Danube and the Dniester. The ecclesial organization of the Orthodox serfdom in Transylvania, which surely inherits ecclesial structures of ancient Bulgaria that conquered the salt mines are from the Avars and the Gepids, set up an Orthodox structure for their miners and agricultural workers; this was probably subject to Bulgarian aristocrats, or maybe directly to the tsars. This organization replaced the old Hungarian nobility that came with Árpád and was assimilated by Hungarity, which was slightly different from the one in 
Hungary under Slovakia's influence. Being different linguistically and religiously, gave rise to Ladislaus Kan's resistance, but gave kinship with Árpád's family (Sarolta, Gyula's mother, he probably descended, through women, from these Bulgarian nobles in the area of the salt mines or the gorges from the Carpathians to the Danube and to the residence of the tsarate or to the great salt markets of Byzantium nobility that cannot be related to the new waves coming in the $14^{\text {th }}$ century, of Orthodox population), was the main reason of the existence of Orthodox Christianity in hilly eastern Hungary, in the Someş rivers area or in the border area with the Cumans' lands.

In other areas such as Hațeg or Maramureş, a new ecclesial organization was founded, related to the Serbian Church, which, due to its superiority, hierarchically subjugated the old Bulgarian organization (entered under Byzantine subordination after the conquest of Bulgaria by Byzantium). It provided religious assistance to the great nobility and to the Boyars that had founded extra-Carpathian states where they again subordinated the Bulgarian organization to a Serbian one, and then directly to Constantinople, to face attacks from the powerful Bulgarian state led by Asan dynasty (probably related to female ancestors of Basarab family, from where they take their name). We can consider that Bulgarian noble blood entered the genealogical composition of the newcomers, but most likely the descendant of the North-Danubian aristocracy of the first Bulgarian tsarate was reduced to serfdom by the Hungarian kingdom, and then conferred to the new Western Balkan aristocrats who came after 1300. These would be the ancestors of the Orthodox nobility from Transylvania, Banat, Crișana, Maramureș, Moldavia and Muntenia until today. The most remarkable performance of Hungarian Orthodoxy is the maintenance of an Orthodox religious life in the central Transylvanian area, in servitude to large Hungarian families, or to the diocese of Alba Iulia, which seems to be the first large owner in central Transylvania, and the only before the great families brought by the Angevins in the $14^{\text {th }}$ century. It managed the serf population and also enslaved the relatives of the old Transylvanian elite which was destroyed by the Stefanian annexation, heiress of the elite that came with Árpád and of the old Bulgarian elite. We can say that Transylvania was organized as the estate of the diocese of Alba Iulia, which was then colonized in the Balkans, Germany, western Hungary or the extraCarpathian Cuman-Pecheneg (Kan Family) areas. However, the persistence of an Orthodox religiosity in the center of Transylvania can also show the presence of older domains of the great noble families brought in the $14^{\text {th }}$ century, entered through marriage or deprival in the possession of the families faithful to the Angevins in the disturbances of the $14^{\text {th }}$ century. However, there is no documentary evidence for this.

After the $14^{\text {th }}$ century, we see the Hungarian Catholic population brought to the area of the salt mines. We know this because they spoke Hungarian with Slovak elements as it is spoken by the Hungarians from central Hungary. Slovak elements cannot connect the current Hungarians from Transylvania, and the 
Szeklers to the old Árpádian Hungarians who achieved the conquest, but who got detached ethnically through marriages between the descendants of the great Moravian nobility with the descendants of the old Catholicized Hungarian chiefs. It was likely Stephen I of Hungary who gave the land of Transylvania to the diocese of Alba Iulia to diminish the resistance of the Transylvanian Orthodox aristocracy and its church, as well as that of the alliances with Byzantium and the Danube line kept by the Byzantines, and populated by Slavic aristocrats or Pecheneg-Cumans to which a peasantry of a similar ethnicity was subject. The Battle of Kossovopolije (1389) would remove the area of Eastern Europe from the only angle from which it was seen until then, namely the anti-Orthodox spread of Catholicism led by the pope, and led to a change in the attitude of the great European nobility towards Orthodoxy; this would be through the death of the Tsar Lazarus, the first crusading king killed in battle against the unbelievers. Thus, the Order of the Dragon was founded, in which Stefan Lazarević will talk about the Battle of Kossovopolije, and declare the death of his father that must be avenged. This creates the chivalrous idea of choosing the Kingdom of Heaven, Vidovdan becomes obvious, an idea found in heraldry and words, or in the fresco that makes Lazarus the ancestor of the Basarab family, which he places in the succession of the holy Serbian monarchy.

The interest shown for Orthodoxy in Western Europe gave rise to a proOrthodox current that led to reform in Germany which was experienced before in these religious currents by the Byzantinizing synods organized by Sigismund in Konstanz and Basel under the certain influence of Stefan Lazarević, and of the description of his great crusading experience within the Order of the Dragon. We can say that these two synods are the attempt of the Order of the Dragon to reannex an acephalous West with a three-pope ordination and distrust of the Orthodox Church. This attempt of the great despotic Roman-Byzantine imperial tradition still had the prestige of the important old Byzantine power which was continued by the Serbians and the Russians. They were allies of Sigismund in front of the Poles and the Italians who would go on the Florentine line of uniation. It is no coincidence that Sigismund was supported by the aggressively Catholicizing Orthodox Russian boyars, subject to Poland-Lithuania, bringing forth the idea of converting King Sigismund to Orthodoxy, but also the Tismana legend about Nicodemus's conversion of Sigismund, in the Serbian royal tradition of Ladislaus's conversion (or Andrew's, according to some variants) to Orthodoxy by Sava, through which they tried to integrate the Hungarian monarchy into the idea of the holy Serbian dynasty, to which the colonized boyars and then country founders to the east of the Carpathians were bound, even trying to apply it for them ("our holy ancestors" as it appears in the documents referring to the necropolis from Rădăuți). 


\section{Matthias Corvinus and the Fight for Serbia}

On the other hand, Matthias Corvinus, in the spirit of tradition, appeared due to the deep ties between his ancestors and the Serbian nobility and royalty. He said that the kings of Serbia were his ancestors, and worshipped the relics of Maxim Branković's ancestors as his relatives without a doubt in Buda. He tried, inspired by the model of Serbian canonization, to Maxim himself in the old tradition of the holy Serbian dynastic royalty, to canonize even his father, John, in Rome. It is Serbian Orthodoxy camouflaged in Catholicism that made it invulnerable to the attack of the great Hungarian nobility. A similar process of infiltration of the upper Balkans in culture and economic and diplomatic agility as the one Hungary went through between the $13^{\text {th }}$ the $16^{\text {th }}$ centuries, cases that reach their peak through the Corvinus royalty and Hunyad and Corvinus crusade system created by it, takes place in the Romanian Lands with the Greeks, who from infiltrations and anti-Ottoman refuges, come to power repeatedly since the $17^{\text {th }}$ century in both countries with strong noble parties.

The Wallachian nobility in relation to Corvinus family had a complex attitude. It is about a space of great importance for the Late Crusade, which began to be integrated into European crusade projects since Sigismund of Luxembourg, through the participation of Wallachian boyars in the Battle of Kossovopolije, which led to the creation of an aristocratic pattern related to the military struggle within its nobility. The Battle of Kossovopolije, beyond the controversy surrounding its unfolding, is the first Orthodox crusade attempt, which relaunched the idea of chivalry after a certain passivity that followed the traditional crusades. ${ }^{7}$

In the case of Muntenia, the nobility acquired a new sense of solidity, which it has not had since the founding of the state and perhaps since the creation of the states in the south of the Danube in which it was certainly somehow involved. The Wallachian nobility expressed its willingness to participate in the crusade several times: at Nicopolis (1396), at the second Kossovopolije, at the Stefanian battles, etc. It is an assumed military fighting tradition.

Matthias Corvinus's (1458-1490) policy in south-eastern Europe is deeply linked to the interests of the battle for Serbia. The reasons for Matthias Corvinus's involvement in Serbia were strategic, but are justified by his genealogical links with this space. All the genealogical successions that link the Corvinus to the Basarab family played an important role in the structure of the Hungarian kingdom's politics. Matthias Corvinus acted in Southeast Europe as the leader of the Late Crusade. All local leaders, Branković, Basarab or Bogdan, acted under the coordination of his court. The foundations of this reality were laid in the time of

7. Pavel Chihaia, Învăţături şi Mituri în Ţara Românească (Constanța: Ed. Ex Ponto, 2010). 
John Hunyadi, ${ }^{8}$ who coordinated the actions of Moldavia, Wallachia and Serbia with a royal power whose source remains to be clarified, but which power must be linked to genealogical connections and successions established during the period when Stefan Lazarević played a very important role in the area, especially through his position as the first knight in the Order of the Dragon (1408).

References to the Serbian and Constantinian ancestry of the Muşatins, but also to their Hungarian female ancestry, the memory of Bogdan's wives or his ancestors', and to the relationships between the kingdom and the Serbian Church through St. Sava and Stefan Prvovenčani (1196-1227) with Ladislaus's Hungary, in which we see a archetype for Nicodemus and Lazarević's relationship with Sigismund of Luxembourg (1387-1437) and George (Maxim) and Jovan with Matthias Corvinus, but also the memory of the genealogical kinship between the Hungarian king, Ladislaus, and the Serbian king, was a symbolic transfer of Serbian holy royalty to Hungary. Thi was a kinship that could also be possible for Matthias with the late Serbian rulers and with the Muntenians, which show us a Serbian ideological program that can be dated from the time of Stefan Dušan and the Orthodox political separations conducted with Serbian church support from Muntenia and Moldavia.

We are dealing with another facet of the Hungarian monarchy, an Orthodox dimension, which was functional in the noble Orthodox circles of Hungary, among which comes Matthias, who wrote to the pope that he can convert Hungary in three days to Orthodoxy (with the help of the great Serbian nobility and the black army obviously), and thus also appropriates the dimension of the conversion to Orthodoxy from Vladislav in the legend of Voskresenkaya and Sigismund (who also makes donations to Tismana ${ }^{9}$ in a Lazarević succession which through Cilli family connected him as they did with Vladislav in the legend of Serbian despots and who appears in the imaginary of the legend of Tismana and the Ruthenians' as mentioned in Dluglosz's Polish History as a convert to Orthodoxy ${ }^{10}$ ). There is another legend about the conversion of Andrew II (1205-1235) to Orthodoxy. John's donations for Tismana are perfectly integrated. We are dealing with an idea that contrasts with the Catholic policy of the Corvinus's, and that shows a Hungary with complex realities.

I also believe that there are connections between Vlad Dracul's mother and the great Buzau nobility, and grandparents such as Pârscov, Bolintin, Bucșani, Ciulnița (where an enigmatic brother of Mircea the Elder [1386-1418] is attested)

8. George Barițiu, “Ioan Corvin de Hunedoara. Originea, genealogia, faptele sale immortali," in Transilvania. Foia Asociatiunei transilvane pentru literatura romana si cultura poporului romanu, edited by John Corvinus Hunyadi. Sheet of the Transylvanian Association for Romanian Literature and Culture of the Romanian People, Year VI, no. 5$10,1873$.

9. DRH, B, I, doc. 97: 168-171.

10. Ioannes Dlugoss, "Historia Polonica," in Ștefan cel Mare și Sfânt 1504-2004, Portret în cronică, 158-172 (Holy Monastery Putna, 2004). 
and the ancestors of the Razbici-Sărățeanu family, made the estate Sărata an old estate of Draculea family, where Vlad Vintilă (1532-1535) had courtyards, inherited of course. Power was exercised during this period by a small group of people, related to the monarchs involved in the battle of Kossovopolije, which John exceptionally reissues showing sensitivity to the sacralization of the battle through the death of the monarch, the cult of Lazarus in Serbia, and obviously in the Serbian epic in which the Brankovićs appear as traitors, and through what Lazarević (1389-1427), as first knight, spoke of this battle in the Order of the Dragon, a battle that became a model for his knights.

This period was continued by the influence of the Brankovic family, during the period of Neagoe Basarab (1512-1521), a ruler married to Maxim's niece, Milița, and by the policy of Rareș, married to her sister, Elena, who somewhat prepared the actions that followed of the Grand Vizier Mehmet Sokolovici and of his brother Macarie Sokolovici (canonized). They, to a subtle extent, coordinated with their relative, through Jakšić, Ivan the Terrible. This is the period when the Hilandar Monastery received large donations. The two families, Craiovescu and Rareș, were continued by their relatives Brâncoveanu and Movila, who dominated the political scene and created the legitimate lines of succession in these two states. The memory of the relatives of these families, such as Prăjescu or Bărbătescu, being that they descended from Serbian despots. We can say that Matthias Corvinus's line of Serbian politics was defining for his geopolitical action, and here we can see his ideational succession of Serbian kings, an asserted succession (atasov suos regis bulgariae).

\section{Serbian-Roman-Vlach Aristocracy}

It is obvious that the Romanian population does not descend from the Roman colonists left in Trajan's Dacia; that is, the continuity in Dacia is a romantic, noble, but unrealistic conception.

Lack of archaeological discoveries of Byzantine Christian churches and cemeteries until the $13^{\text {th }}$ century in north of the Danube and the beginning of the western ones in the $11^{\text {th }}$ century clearly, shows the coming of the Orthodox population from the southwest, a phenomenon that can be related to the claim of Stefan Dragutin (who may be through linguistic alteration "Negru Vodă," as well as the Stefan honored in the royal hall of Radu the Great and by Muntenian singers).

Thus, the high Slavic-Roman bilingual Serbian aristocracy could come to the areas of Hungary that supported Stefan Dragutin (1276-1316) and Stefan Vladislav (1316-1325), his son (probably the one who was buried under the effigy tomb from Argeș, today at the Museum of National History of Bucharest). These areas were under the influence of Ladislaus Apor and Ladislaus Kahn (1296- 
1315), who were both related to the Nemanid family from northern Serbia and southern Hungary mentioned.

It is likely that both the Wallachian dynasty and the Moldavian dynasty have direct genealogical links with this chain of northern Serbian kings. Stefan Dragutin, the great usurper (both in southern Serbia by his younger brother Milutin and the son of the Angevin married to his Árpádian mother's younger sister); Charles Robert of Anjou (1308-1342), because Katerina, present in Câmpulung chronicles as Negru Vodă's wife is the older sister of Charles Robert of Anjou's mother), ${ }^{11}$ who may be the proof of the group of Serbian sovereigns who wear heraldically in their coat of arms, either simply (as in Bogdan or Lazarević, the classic "Lazarevic'" crest), or with raven-griffon ornament (as in Vladislav Vlaicu (1364-1377), the raven being the old symbol of Cumania, and the horned helmet of the Srem dynasty mentioned). ${ }^{12}$

In this context, the imperial succession, the massive presence of the title of "tsar" and the donations to Mount Athos are no longer the result of a "transaltio imperii," but are the result of the full belonging of entire Moldova and Wallachia to the Balkans, both through the origin of the dynasty and aristocracy, and through religious affiliation to Orthodoxy, the only Christian community that resists legitimately without rebellion in its history (as the rebellion of the pope against synodality or Monophysites, etc.), the apostolic roots.

Thus we have an explanation for the art and architecture of the Romanian space, as well as for the whole Romanian Byzantine liturgical civilization. Adrian Andrei Rusu's considerations about pagan Romans in the north of the Danube, ${ }^{13}$ arbitrarily postulated, and thus affirmed based on the reality of the non-existence of tombs and churches before the $11^{\text {th }}-12^{\text {th }}$ centuries (Byzantine $13^{\text {th }}$ century) definitively exclude ethnogenesis in the north of the Danube. It is impossible for the language developed by the Aromanians, for example, who have Christian continuity, to be identical with the language spoken by "Dacian-Romanians," who were supposed to have a vast pagan stage, according to the Cluj scientist trying to save continuity.

The expansion of Serbian civilization following Dragutin's Hungarian royal claim to the extinction of the Árpádian dynasty, its assimilation of Hungarian and Pecheneg-Cuman aristocratic elements that integrated into the Moldavian and Muntenian aristocracy, and the homogeneous Orthodox character of this aristocracy and the certain presence of the Serbian-Byzantine imperial ideology around the North Danube "landlords," gives meaning to an obvious reality: Moldavia and The Romanian Country-Wallachia are the state vestiges of a

11. Stefan Staretu, Europe: Serbian Despotate of Srem and the Romanian Area: Between the $14^{\text {th }}$ and the $16^{\text {th }}$ Centuries (SUA: Derc Publishing House, 2018).

12. Dragomir M. Acovic, Heraldika i Srbi (Beograd: Zavod za Utbenike, Beograd, 2008), 32.

13. Adrian Andrei Rusu, Castelul și spada: cultura materială a elitelor din Transilvania în Evul Mediu târziu (Cluj-Napoca: Ed. Mega, 2019), 829. 
Northern Serbian Kingdom-Kingdom of Srem - founded by Dragutin, which went through the experience of trying to absorb Hungary, on the clear basis of the rights of dynastic succession (the Angevins are usurpers by genealogy, but supported by the papacy).

The grafting of a Cuman element to the Muntenian dynasty, which did not necessarily give the trunk of the succession (the name Radoslav-Vladislav, RaduVlad specific to Dragutin's family, dominates the Muntenian genealogy, in relation to Basarab isolated family), grafting postulated by Mr. Djuvara, ${ }^{14}$ does not change the Serbian-Romanian cultural landscape of the Wallachian monarchy.

From this perspective, the immigrationist theory of Romanian ethnogenesis must be translated from the model of pastoral migration to the model of aristocratic and royal migration. The mistake of Hungarian historiography is not in presenting the phenomenon, but in postulating the social status of those who came.

The legend of Roman and Vlahata remains a distorted form of myth and mythology of this phenomenon. The attempts of imperial succession in Serbia, or even Byzantium of Stephen the Great, Neagoe Basarab, Petru Rareș or Alexandru Lăpușneanu, the traces of a dynastic cult around them came precisely from their discovery in the posterity of the holy Serbian dynasty, no longer seem so awkward, as well as "The Lament of Ivan Peresvetov," 15 the icons of Saints Simion and Sava in all monasteries and churches from "Bucovina" or Argeș in the crowning and funerary space par excellence of the Wallachian dynasty, or the presence of the term Axial Vidovdan term in the Teachings of Neagoe, appear to us as natural phenomena.

I consider that both Lazarević and Bogdan or the Wallachian dynasty improperly called "Basarab" must have their origin in the succession of Stefan Dragutin, Serbian Moravia (also called Lazarus's Wallachia in documents), or Hungarian-Wallachia even coinciding territorially with the state of these Nemanid kings and Árpádian monarchs. The belonging to the Serbian Orthodoxy of this ensemble is undeniable, being demonstrated by the architecture, hagiography and early liturgical language.

The absorption of some elements of Bulgarian imperial ideology (the title of $I O$, taken over by Vladislav Vlaicu after the conquest of Vidin, or elements of title) are related to Vidin's influence on this northern Serbian kingdom, and does not decisively influence the cultural spectrum of the area.

The fact that Srem is listed together with Transylvania, Hungarian-Wallachia and Maramureș in papal and Hungarian documents as being inhabited by

14. Neagu Djuvara, Thocomerius-Negru Vodă-Un voivod de origine cumană la începuturile Ţării Româneşti (Bucharest: Humanitas Publisher, 2007).

15. Ștefan Ciobanu (trans.), Manual de domnie al Țarilor Ruși or Plângerea lui Ivan Peresvetov (Bucharest: Fundației Anastasia Publisher, 2004). 
Wallachians (a term applied by Hungarians for the Serbian-Vlach aristocratic synthesis we are talking about) shows their connection, even in the system conceived by Catholic propaganda for their conversion from Orthodoxy to Catholicism as a form of pope pressure on the Angevins.

It is obvious, in the context of the researches of Messrs. Năsturel, Marinescu and Năstase, that Hilandar was the axial center of the system of donations from Athos of the Muntenian and Moldavian rulers, just as it is obvious that the other group of monasteries based on aids from them is the one from Serbia, not the one from Bulgaria, proof of the Serbian dynastic succession, and not Bulgarian of those called today Romanians (Athos is taken over as a bloc, because it was formed in the time of Dušan as a bloc, Dušan who donated to each of them, including Zografu, where he stayed during his visit).

The phenomena described by Mr. Năstase in his synthesis are too deep to be the result of a cultural mimicry. They are not to be found in the powerful RussianLithuanian Orthodox aristocracy. Families like Ostrogsky, Wiszniovyecky or Holshansky do not enter this game, although financially, they were even stronger than the rulers of Moldova and Wallachia. The phenomenon is different.

The phenomenon says a lot about what medieval Serbia was like and about its posterity in the northern Danube world.

\section{Conclusion}

Serbia, a space of civilization resulting from the fusion of Illyrian Romanians who took refuge in the Dinaric Alps after the Avar invasion, merged with a Slavic aristocracy different from that of the invaders from Bulgaria and Macedonia today. Aristocracy was probably already accepted in the military Byzantine world since the time of Justinian, in a space that developed a Romanian-Slavic bilingualism that is still specific to Serbia. A dual, Serbian geographical identity, after a Byzantine name, and social-ethnic Vlach, radiated on Hungarian power structures to northeast, which is part of an older expansion of the Byzantine influence on Hungary (Bela-Alexios, Elena de Rashka, Stephen V and others).

Stefan Dušan must be seen as the definitive architect of saving Dragutin's claim, the Negru Vodă Na(n)-Grutin double usurped as already stated, in the north, by the defining support of Wallachia and Moldavia against the Angevins, and after the Ottoman expansion, the entire aristocracy there is assimilated in this space, not between foreigners, but as an end to a phenomenon of moving from south to north of Serbia beginning in the $13^{\text {th }}$ century (Branković, Jaksic and other families merged in our nobility and not in other aristocracies, to which we can add the Cantacuzino, who also come as "Serbians").

Tihomir (Negru Vodă), Basarab's father from Hungarian sources, seems to be the same Ștefan Dragutin, the nemanid king dethroned by his younger brother, as detailed above, and then a monk, canonized as the monk Teoctist. The 
name Tihomir, specific to the nemanid dynasty, and present in both the Dalmatian and Bulgarian branches of the dynasty, is the only one that can explain the monastic name of the Serbian king, legitimate heir of the Arpadian dynasty, son of Maria Arpad's older sister, through whom the Angevins would finally usurp the throne of the Hungarian kingdom. Obviously, historiography has approached this discovery in steps, ${ }^{16}$ but following successive clarifications, the following history emerges: Stefan Tihomir, known as Dragutin, the beloved, after his dethronement in Serbia, motivated by pro-Byzantine interests, formed a strong kingdom of colonization, if we can call it that, in a vast area that starts in western Bosnia and ends in Olt, by agglutinating the many bans of the area. The aristocratic colonizations in this area, the establishment of an Orthodox hierarchy that slowly dislocated the Catholic one, the assimilation of most Hungarian nobles in the area through mixed marriages favoring the Orthodox side, ${ }^{17}$ all created in the Kingdom of Srem as an ethnic reality anchored in the civilization of non-Serbian Serbia, the most advanced part of the Arpadian kingdom. The whole structure was deployed in Cumania, part of the Hungarian kingdom east of Olt, but also in the entire Tisa basin, to the area of Mureș Hunedorean or Maramures, following the arrival of the Angevins, who engaged in usurping Dragutin's right to the Arpadian throne with papal support.

The Greeks came to the north also as a result of this inertia from the ancient Dušanian space to the north, and therefore were never considered foreigners in reality, but organically assimilated, as a process of rebuilding the Empire of Serbia and Romania entirely conceived by Dušan, intuited by N. Iorga as Byzantium after Byzantium.

The complexity of the phenomenon places us in the reality and takes us out of the primitivizing mythology of Trajan's Dacian-Romans, pagans, in forests, to suddenly in the $14^{\text {th }}$ century to rise royal, Slavic-Byzantine, and sophisticated.

Indeed, many of today's Orthodox Romanians are the remnant of the posterity of Andrew III, the last Árpádian, of his Serbian posterity, and the Catholic Hungarians, the remnants of his Angevin posterity.

16. Adrian Ioniță, Beatrice Kelemen, Alexandru Simon, AL WA Prințul Negru al Valahiei și vremurile sale (Cluj-Napoca: Academia Română, Centrul de Studii Trnasilvane, Ed. Argonaut, 2017): despre ipoteza originii materne a Basarabilor din ramura lui Ștefan Vladislav, p. 473; Petre Buneci, Bogdan Gâlculescu, Ștefan Dumitrache and Cristian Moșneanu, Ordinul Cavalerilor Basarabi (București: Ed. Neverland, 2020).

17. P. P. Panaitescu, Cronicile slavo-romîne din sec. XV-XVI, publicate de Ion Bogdan, ediție revăzută și completată (București: Editura Academiei R.P.R., 1959). 


\section{Bibliography}

Acović, Dragomir M. Heraldika i Srbi (Heraldry in Srbi.) Beograd: Zavod za Utbenike, 2008. Barițiu, George. "Ioan Corvin de Hunedoara. Originea, genealogia, faptele sale immortali" (The Origin, the Genealogy, His Immortal Deeds.) In Transilvania. Foia Asociatiunei transilvane pentru literatura romana si cultura poporului romanu, edited by John Corvinus Hunyadi. Sheet of the Transylvanian Association for Romanian Literature and Culture of the Romanian People, Year VI, no. 5-10, 1873.

Bojović, Boško I. L'Ideologie Monarchique dans les Hagio-Biographies Dynastiques du Moyen Age Serbe (Monarchical Ideology in the Dynastic Hagio-Biographies of the Serbian Middle Ages.) Orientalia Christiana Analecta 248. Roma : Pontifcio Istituto Orientale, 1995.

Buneci, Petre, Bogdan Gâlculescu, Ștefan Dumitrache and Cristian Moșneanu. Ordinul Cavalerilor Basarabi (Order of the Bassarabian Chivalry.) București: Ed. Neverland, 2020.

Căprăroiu, Denis. "Opinii istoriografice despre unul dintre voievozii cu numele Bogdan din secolul al XIV-lea" (Historiographical Opinions about One of the Voivodes Named Bogdan from the $14^{\text {th }}$ Century.) Analele Universității din Craiova. Seria Istorie XVI, no. 1 (2011): 27-43.

Chihaia, P. Învăţături şi Mituri în Țara Românească (Teachings and Myths in Wallachia.) Constanța: Ex Ponto Publisher, 2010.

Ciobanu, Ștefan (translated). Manual de domnie al Țarilor Ruși (Reign Manual of the Russian Tsars) or Plângerea lui Ivan Peresvetov (Ivan Peresvetov's Complaint.) Bucharest: Fundației Anastasia Publisher, 2004.

Ćirković, Sima. La Serbie au Moyen Age (Serbia in the Middle Ages.) Paris: Zodiaque, Paris, 1992.

Djuvara, Neagu. Thocomerius-Negru Vodă-Un voivod de origine cumană la începuturile Țării Româneşti (A Voivode of Cuman Origin at the Beginning of Wallachia.) Bucharest: Humanitas Publisher, 2007.

Dlugoss Ioannes. “Historia Polonica” (Polish History.) In Ștefan cel Mare și Sfânt 1504-2004, Portret în cronică, 158-172. Holy Monastery Putna, 2004.

Ioniță, Andrian, Beatrice Kelemen and Alexandru Simon. AL WA Prințul Negru al Valahiei și vremurile sale (AL WA The Black Prince of Wallachia and his Times.) Cluj-Napoca: Academia Română, Centrul de Studii Trnasilvane, Ed. Argonaut, 2017.

Ivković, Zorica Zlatić. Stefanu Nemanju povodom 900 godina od rođenja (1113-2013) (Stefan Nemanja on the Occasion of the $900^{\text {th }}$ Anniversary of his Birth (1113-2013)) Beograd: Grafoprint, 2013.

Panaitescu, P. P. Cronicile slavo-romine din sec. XV-XVI, publicate de Ion Bogdan (The SlavoRomanian Chronicles from the $15^{\text {th }}$ Century XV-XVI, Published by Ion Bogdan.) Ediție revăzută și completată. București: Editura Academiei R.P.R., 1959.

Rusu, Andrian Andrei. Castelul și spada: cultura materială a elitelor din Transilvania în Evul Mediu târziu (The Castle and the Sword: The Material Culture of the Elites of Transylvania in the Late Middle Ages.) Cluj-Napoca: Ed. Mega, 2019.

Staretu, Stefan. Europe: Serbian Despotate of Srem and the Romanian Area: Between the $14^{\text {th }}$ and the $16^{\text {th }}$ Centuries. SUA: Derc Publishing House, 2018. 
Székely, Maria Magdalena. Obârșia lui Luca Arbure. O ipoteză" (The Origin of Luca Arbure. A Hypothesis.) In In honorem Paul Cernovodeanu, 419-429. Bucharest: Violeta Barbu Publisher, 1998. 